Research Article, Issue 3
Analytical Methods in Environmental Chemistry Journal
AMECJ

\title{
The importance of microplastics pollution studies in water and soil of Nigeria ecosystems
}

\author{
Verla Andrew Wirnkor ${ }^{\mathrm{a}}$, Enyoh Christian Ebere ${ }^{\mathrm{a}, *}$, Verla Evelyn Ngozi ${ }^{\mathrm{b}}$ \\ ${ }^{a,{ }^{*}}$ Group Research in Analytical Chemistry, Environment and Climate change (GRACE\&CC), Department of Chemistry, Faculty of Science, Imo \\ State University, Owerri, Imo State Nigeria \\ ${ }^{b}$ Department of Environmental Technology, Federal University of Technology, Owerri, Imo State Nigeria
}

\section{A R T I C L E I N F O:}

Received 12 May 2019

Revised form 30 Jul 2019

Accepted 14 Aug 2019

Available online 23 Sep 2019

\begin{abstract}
A B S T R A C T
The ubiquity of microplastics in the environment is a novel problem to scientist, public media, governmental and non-governmental organization. The major problem is from the difficultness in removing them from the ecosystem. Elsewhere studies are being conducted while in Nigeria studies are relatively lacking. Production (10.3\%) and consumption (6.5\%) of plastics is on the increase annually, thereby, causing an increase in the amount of plastic waste generated annually. This is turn may potentially causing high microplastics pollution in Nigeria. Many reports have shown that microplastics could cause harm to man, animals and plants and exposure (or ingestion) could come from air, water and soil. Few studies have been conducted in Nigeria and reports have suggested high abundance of microplastics in Nigeria freshwater system. Following these observations, there is a clear need for more detailed studies focusing on the quantitative and qualitative determination of occurrence of microplastics in Nigeria ecosystem. Finally, from such studies, data generated will provide insight and understanding into the extent of microplastic pollution in Nigeria. Furthermore, the data will be important not only for both remediation and minimization of effects, but could be employed in averting occurrence through policies such as ban on some types of plastic uses in Nigeria. In this study, four manually generally microplastic types (PVC, acrylics, polyesters, silicones) were evaluated for heavy metals ( $\mathrm{Pb}, \mathrm{Cd}, \mathrm{Hg}$, and $\mathrm{As})$ adsorption at optimized $\mathrm{pH}$ by ETAAS.
\end{abstract}

\section{Introduction}

According to Plastic Europe [1], producing and using plastics are vital in creating a more sustainable future because of specific properties including their light-weight, versatility and durability. However, the proposed sustainable future is not sustainable since plastic (including macro, meso and microplastics) pollution is now potentially deleterious and harmful to global ecosystem. As an increasing global issue, microplastic (from the degradation of macroplastic) contamination in

Corresponding Author: Enyoh Christian Ebere

Email:*Cenyoh@gmail.com,verngo@yahoo.com

https://doi.org/10.24200/amecj.v2.i03.69 marine, terrestrial and atmospheric environments is attracting significant attention from scientists, policy makers, and the public [2-7]. Microplastics are now naturally ubiquitous and have been detected in pelagic and neritic regions, deepest part of the ocean and highest (Tibetan Plateau) plateau of the world in significant quantities [6, 8-10]. In an effort to combat microplastic pollution, many governments in different continents worldwide have banned plastic use (especially single-use) and are encouraging recycling of plastics. Notable continents include Europe (England, Italy, Wales, Scotland, Germany),Asia(India, China, Bangladesh, Cambodia, Hong Kong, Indonesia, Malaysia, and 
Taiwan), Australia, America (California, certain areas in Argentina, Brazil, Chile, and Colombia) while some African countries (Kenya, Mali, Cameroon, Tanzania, Uganda, Ethiopia, Malawi, Morocco, South Africa, Rwanda, and Botswana) have also banned plastic bags [11], though in principle but not in practice. In Nigeria, the problem of plastic pollution still persist and potentially on the increase, even though there are existing laws that may tackle these problems [12], but are not implemented or are poorly enforced [13]. Plastic industry in Nigeria is receiving massive investment and thus experiencing significant growth. In Sub-
Sahara Africa, excluding South Africa, Nigeria is the largest importer of plastics technology. The plastic types produced and imported in Nigeria are thermoplastics comprised mainly of polypropylene (PP), polyamide (PA; PA6 + PA66), polyethylene terephthalate resin (PET), polyethylene (PE; high density-PE, low density-PE, Linear low-density$\mathrm{PE}$ ), poly vinyl chloride (PVC), polystyrene (PS), acrylonitrile butadiene styrene (ABS), styreneacrylonitrile resin (SAN) and polycarbonate (PC) [14]. There is a strong steady increase in plastic production (Figure 1) and consumption (Figure 2) in Nigeria (with negligible recycling). In the last

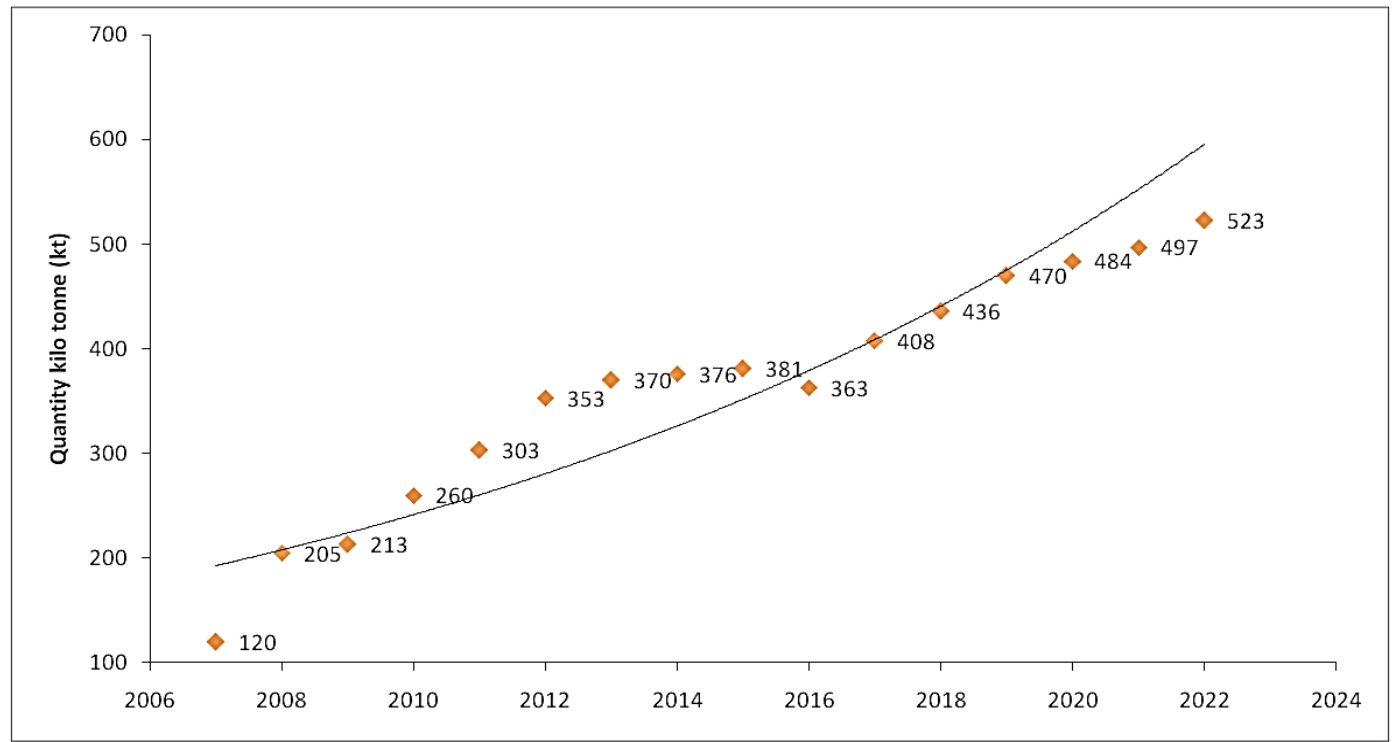

Fig. 1. Plastic production in Nigeria (Data source: [14]).

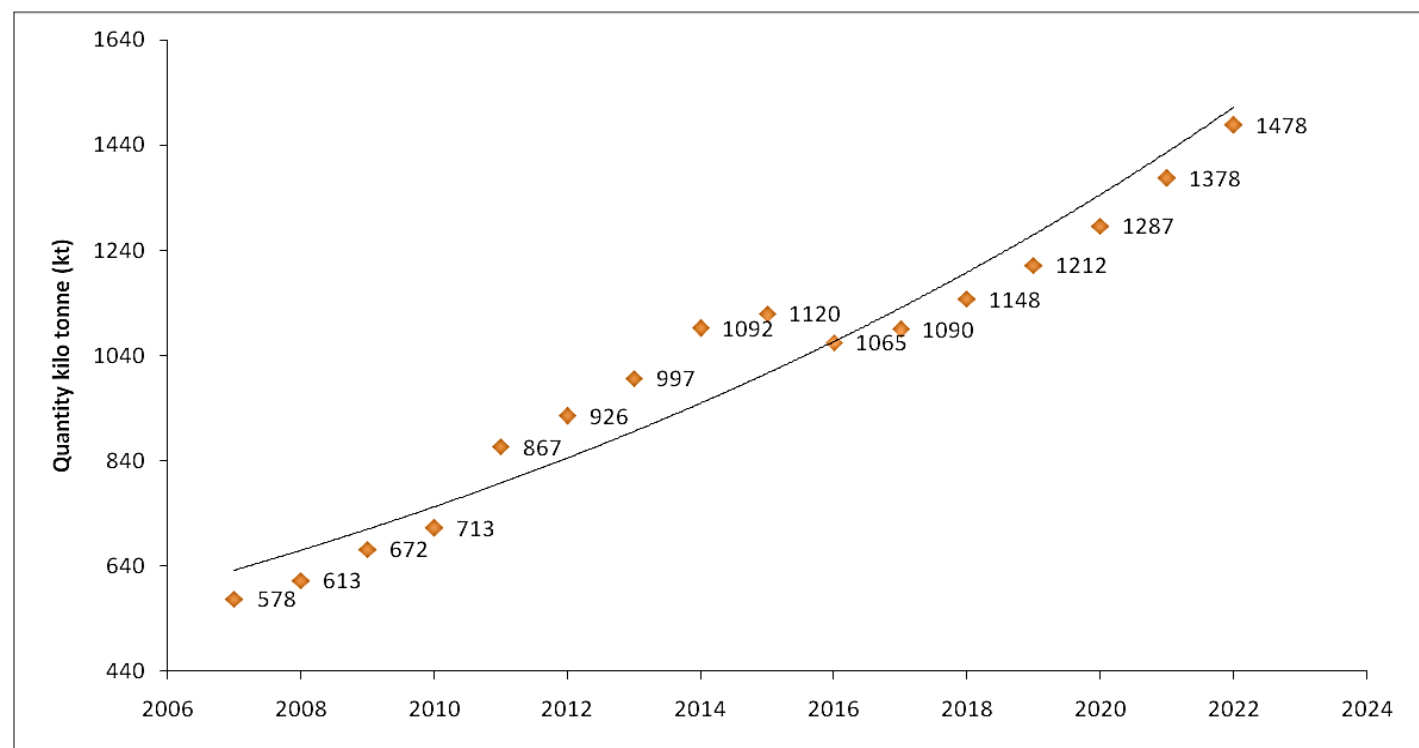

Fig. 2. Plastic consumption in Nigeria (Data source: [14]). 
decade, Nigeria's plastics production has grown by $10.3 \%$ annually, from $120 \mathrm{kt}$ in 2007 to $436 \mathrm{kt}$ in 2018 and is estimated to be $523 \mathrm{kt}$ in 2022 while consumption (by application) has grown by $6.5 \%$ annually, from $578 \mathrm{kt}$ in 2007 to $1.148 \mathrm{kt}$ in 2017 and is estimated to be $1.478 \mathrm{kt}$ in 2022 (Figure 2). Majority of plastic consumed (by application) is by packaging (55\%), $16 \%$ by construction, $6 \%$ for automotive and the remainder by various industries. So it is expected that the problem of microplastic pollution will increase as well (Figure 3), since there are currently no measure for curbing plastic waste in Nigeria. It is estimated that $10 \%$ of plastic consumed annually in Nigeria end up as wastes in the environment and may continue to rise with increasing population. According to the estimates of United nations environment program [15], 6.4 million tons of plastic litter enters the world oceans each year, of which Nigeria is a major contributor ( $9^{\text {th }}$ largest emitters), largely through the river Niger [16]. The river receives its wastes mainly from inland waterbodies in the country. Furthermore, 90 $\%$ of all the plastic that reaches the world's oceans are from ten countries, with Nigeria as one of them [17-18].

Plastics persist in the environment and can "outlive" humans by several hundred years (e.g PET degradation time ranged from 450-1000 years while average lifespan of human is $<100$ years). So the first produced plastics in 1907 called "Bakelite" may still be in the environment till now (if not recycled). Sadly, plastic production in Nigeria is on the increase annually. The steady and huge increase in production and consumption is responsible for high plastic waste generation in Nigeria (Figure 3). Recent studies have shown that plastic is abundance in inland freshwater systems in Nigeria, often received from cities via surface run off [13]. Enyoh et. al., in 2019 [13] reported that plastic contributed $59 \%$ of the 3487 macrodebris items $/ \mathrm{m}^{2}$ counted from shore of Rivers in Nwangele Local Government Area of Imo state. Similarly, a study of Cross River, Qua Iboe River and Jaja Creek in Akwa Ibom, Nigeria for suspended marine litter also reported high quantity of plastic $(>5000 \mathrm{~kg} /$ $\mathrm{m}^{2}$ ) compared to other waste (can, foil etc $<1000$ $\mathrm{kg} / \mathrm{m}^{2}$ ) [19]. Reports have shown that Macroplastics correlated strongly with microplastics indicating that wherever there is high abundance of macroplastics, there will be a corresponding high abundance of microplastics in that area $[13,20]$. Therefore, quantifying the abundance of microplastics and identifying their major sources in Nigerian environments is important to understand the potentially adverse impacts of microplastics to ecological systems in the country.

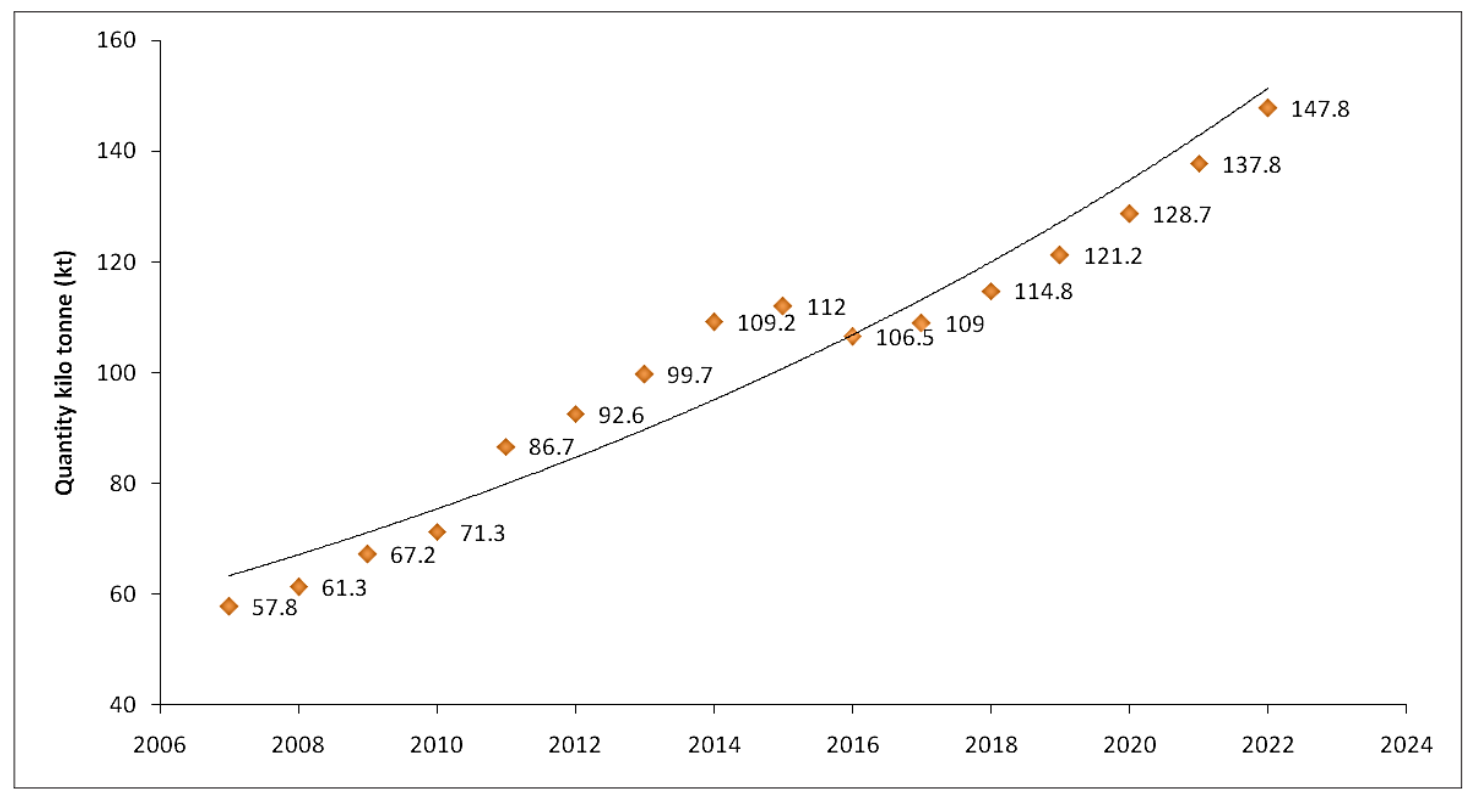

Fig. 3. Plastic waste (estimated) generated from plastic consumption in Nigeria 
Extensive studies are being conducted in other countries regarding the occurrence, fate, and implication of microplastic in ecosystems [3$4,6,8,21-23]$, while similar studies in Nigerian environment are very scarce [13]. This is probably due to lack of awareness and/or lack of standard methods for analysis [24]. Many people including government officials and health workers are not aware of the dangers associated with microplastic pollution because they have been taught that plastic is a safe material. Microplastics can serve as vectors to toxic chemicals in the environment and due to their small sizes; they can easily be ingested, where it may pose particle and chemical toxicity as well as microbial toxins through formed biofilm [6]. To the best of our knowledge, few studies $(n=3)$ covering 7 areas have been conducted in Nigeria till date (Table 1). Three invertebrates (L. varicus., M. tuberculata and T. fluviatilis) studied from Osun river system as bioindicators for microplastics pollution in Nigeria revealed high quantity of fibre and three polymer types via PE, PP and nylon [25]. Briggs et al., focused on method development, however from re-interpretation of their results, one could say that there is high abundance of microplastics in surface water from Elechi creek (an area which experiences petroleumindustry related activities) [26]. Reconnaissance survey indicated that microplastics may be made up of PE, PS, PET and PA [26]. Enyoh et. al., in 2019 [13] reported small microplastics $(11 \mu \mathrm{m})$ in surface water of Obiaraedu, Nwangele, Okumpi, Ogbajarajara and Onuezuze rivers which ranged from 440 to 1556 particles per liter. The shapes were generally fibre, film, fragment with PET, PE, PVC, PP as types of polymer. Overall studies have implicated significant microplastics pollution in Nigeria linked to anthropogenic activities.

Table 1. Available studies on microplastics in Nigeria ecosystem

\begin{tabular}{|c|c|c|c|c|c|c|c|c|c|}
\hline \multirow[t]{2}{*}{ Study area } & \multirow[t]{2}{*}{ Region } & \multirow[t]{2}{*}{ Media studied } & \multirow{2}{*}{$\begin{array}{l}\text { Method } \\
\text { used }\end{array}$} & \multirow[t]{2}{*}{ MP load } & \multicolumn{3}{|c|}{ Characteristics } & \multirow[t]{2}{*}{ Remark } & \multirow[t]{2}{*}{ References } \\
\hline & & & & & $\begin{array}{l}\text { Size } \\
(\mu \mathrm{m})\end{array}$ & $\begin{array}{c}\text { Polymer } \\
\text { type }\end{array}$ & $\begin{array}{c}\text { Shape/ } \\
\text { form }\end{array}$ & & \\
\hline $\begin{array}{l}\text { Osun River } \\
\text { (Osun state) }\end{array}$ & $\begin{array}{c}\text { South } \\
\text { Western, } \\
\text { Nigeria }\end{array}$ & $\begin{array}{l}\text { Invertebrates } \\
\text { (L. varicus., } M \text {. } \\
\text { tuberculata and } \\
\text { T. fluviatilis; as } \\
\text { bioindicators) }\end{array}$ & Micro-FTIR & $\begin{array}{c}1.71 \pm 0.46 \\
\text { to } 6.1 \pm 1.05 \\
\text { per g }\end{array}$ & 0.2 & $\begin{array}{c}\text { PE, PP, } \\
\text { nylon }\end{array}$ & $\begin{array}{l}\text { Fibre, } \\
\text { Film }\end{array}$ & $\begin{array}{l}\text { Gives the } \\
\text { first chemical } \\
\text { identification of } \\
\text { polymer types } \\
\text { in freshwater } \\
\text { invertebrates }\end{array}$ & [25] \\
\hline $\begin{array}{l}\text { Elechi creek } \\
\text { (Rivers state) }\end{array}$ & $\begin{array}{l}\text { South } \\
\text { South, } \\
\text { Nigeria }\end{array}$ & Freshwater & N/A & N/A & N/A & N/A & N/A & $\begin{array}{l}\text { Work document } \\
\text { for the first time, } \\
\text { the sampling and } \\
\text { sample extraction } \\
\text { of microplastics in } \\
\text { Nigeria. }\end{array}$ & {$[26]$} \\
\hline $\begin{array}{l}\text { Obiaraedu, } \\
\text { Nwangele, } \\
\text { Okumpi, } \\
\text { Ogbajarajara } \\
\text { and } \\
\text { Onuezuze } \\
\text { rivers (Imo } \\
\text { state) }\end{array}$ & $\begin{array}{l}\text { South } \\
\text { Eastern, } \\
\text { Nigeria }\end{array}$ & Freshwater & Microscopy & $\begin{array}{l}440 \text { to } 1556 \\
\text { particles/L }\end{array}$ & 11 & $\begin{array}{l}\text { PET, } \\
\text { PE, } \\
\text { PVC, } \\
\text { PP }\end{array}$ & $\begin{array}{c}\text { Fibre, } \\
\text { Film, } \\
\text { Fragment }\end{array}$ & $\begin{array}{l}\text { First report on MP } \\
\text { quantification, } \\
\text { distribution and } \\
\text { composition of } \\
\text { freshwater MP in } \\
\text { Nigeria. Results } \\
\text { from the study } \\
\text { indicated high load } \\
\text { of microplastics and } \\
\text { provided baseline } \\
\text { information for } \\
\text { future assessments }\end{array}$ & [13] \\
\hline
\end{tabular}

N/A- not reported, FTIR-Fourier Transform Infrared Spectroscopy. 
In Nigeria, knowledge about microplastic contamination of the ecosystem is still negligible, while such studies have been conducted elsewhere, especially in Europe, Asia and America. Preliminary studies show that in Nigeria there are microplastics in freshwater system and may be on the rise with increasing plastic production and consumption. There is a clear need for more detailed studies focusing on the quantitative and qualitative determination of occurrence in Nigeria ecosystem [air (indoor and outdoor), soil (including soil animals) and water (surface and groundwater)] Such studies will provide insight and understanding into the extent of microplastic pollution in Nigeria. Importantly, increasing attention and studies on atmospheric microplastic pollution would be particularly beneficial to the protection of ecosystems in Nigeria, since the country is most polluted in Africa and fourth in the world regarding air pollution [27]. Furthermore, studies have shown that microlastics may be consumed from open meal in the house from indoor airborne microplastics during fall out and high during cooking periods $[8,23]$. Finally, similar studies would be very important in Nigeria, where cooking is mostly done with stoves, charcoal, firewood etc. Furthermore, habits such as microwaving of food are rampant in Nigeria. This has been fingered as one possible way by which microplastics enter our food.

As stated earlier, heavy metals (with adverse effects associated with mutagenic, teratogenic and carcinogenic effects [28]) can be absorbed on microplastics and introduce as a major problem in environment [6]. Many methods used for determination heavy metals which were absorbed on microplastics from waters [29-32]. In an attempt to study this phenomenon, four manually generally microplastic types (PVC, acrylics, polyesters, silicones) were evaluated for heavy metal adsorption. Heavy metals such as $\mathrm{Pb}, \mathrm{Cd}$, $\mathrm{Hg}$, and As was used with different concentration from 100-1000 $\mu \mathrm{g} \mathrm{L}^{-1}$ in batch system with 20 $\mathrm{mg}$ of microplastics by vary times (min). Results showed in $\mathrm{pH}=3-6$ high adsorption was achieved by surface of microplastics (PVC) at $60 \mathrm{~min}(\mathrm{pH}=4$ 5). After, $60 \mathrm{~min}$. the heavy metals desorption from PVC powder $(1 \mathrm{~g})$ with nitric acid $0.5 \mathrm{M}(5 \mathrm{~mL})$ and after dilution with $5 \mathrm{~mL}$ of DW, determined by atomic absorption spectrometry (AAS). The results showed, the adsorption capacity for $\mathrm{PVC}$ for $\mathrm{Hg}, \mathrm{Pb}, \mathrm{Cd}$, and As was obtained 68.4 $\mathrm{mg} \mathrm{g}^{-1}, 52.3 \mathrm{mg} \mathrm{g}^{-1}, 48.5 \mathrm{mg} \mathrm{g}^{-1}$ and $35.6 \mathrm{mg} \mathrm{g}^{-1}$, respectively $(\mathrm{Hg}>\mathrm{Pb}>\mathrm{Cd}>\mathrm{As})$. So, microplastics (PVC powder) help in the removal heavy metals from waters and convert to new solid pollution in waters which must be removed (Fig. 4-6).

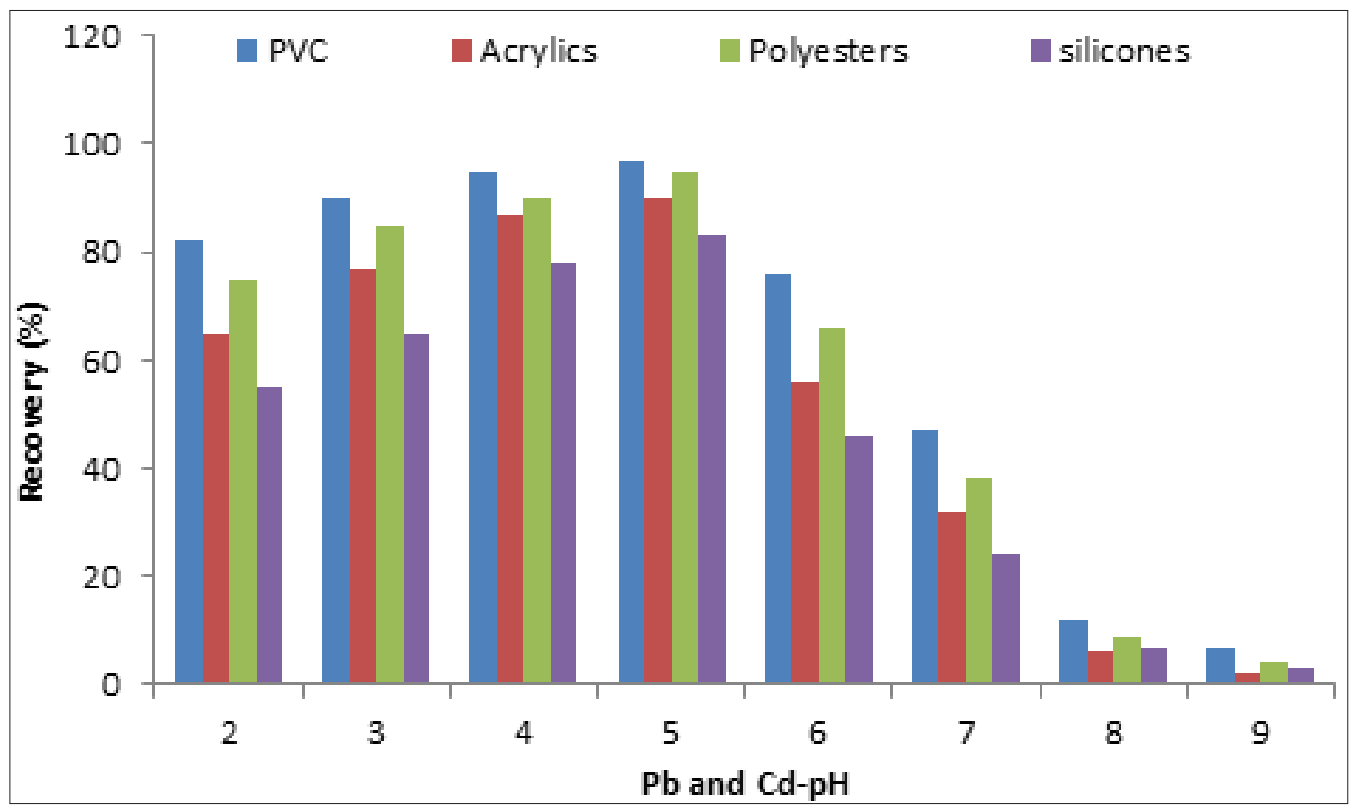

Fig. 4. The effect of $\mathrm{pH}$ on lead and cadmium extraction by microplastics 


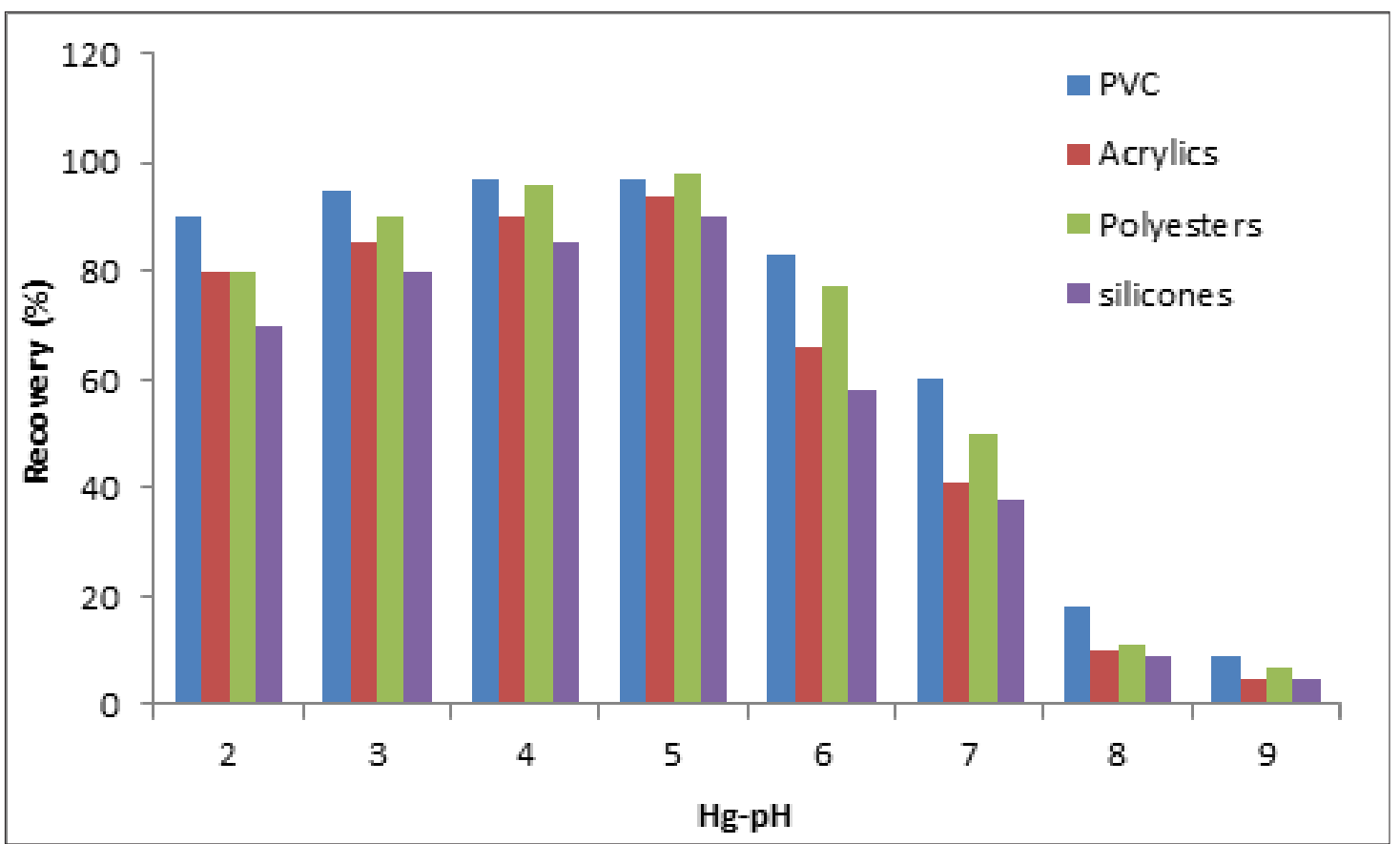

Fig. 5. The effect of $\mathrm{pH}$ on mercury extraction by microplastics

\section{Conclusion}

Microplastic studies are conspicuously absent from the huge volumes of journal papers from Nigerian authors. This unawareness is exacerbated by the general belief that plastics are nontoxic, biochemically inert and safe. Researchers elsewhere in the world are exploring the validity and veracity of this statement with many proposing that plastics degrade to microplastics and are responsible for the environment pollution called microplastics pollution. Occasionally microplastics absorbed toxic heavy metal from liquid matrix such as sea and rivers. In Nigeria, studies are not even a foot in understanding this pollution not to

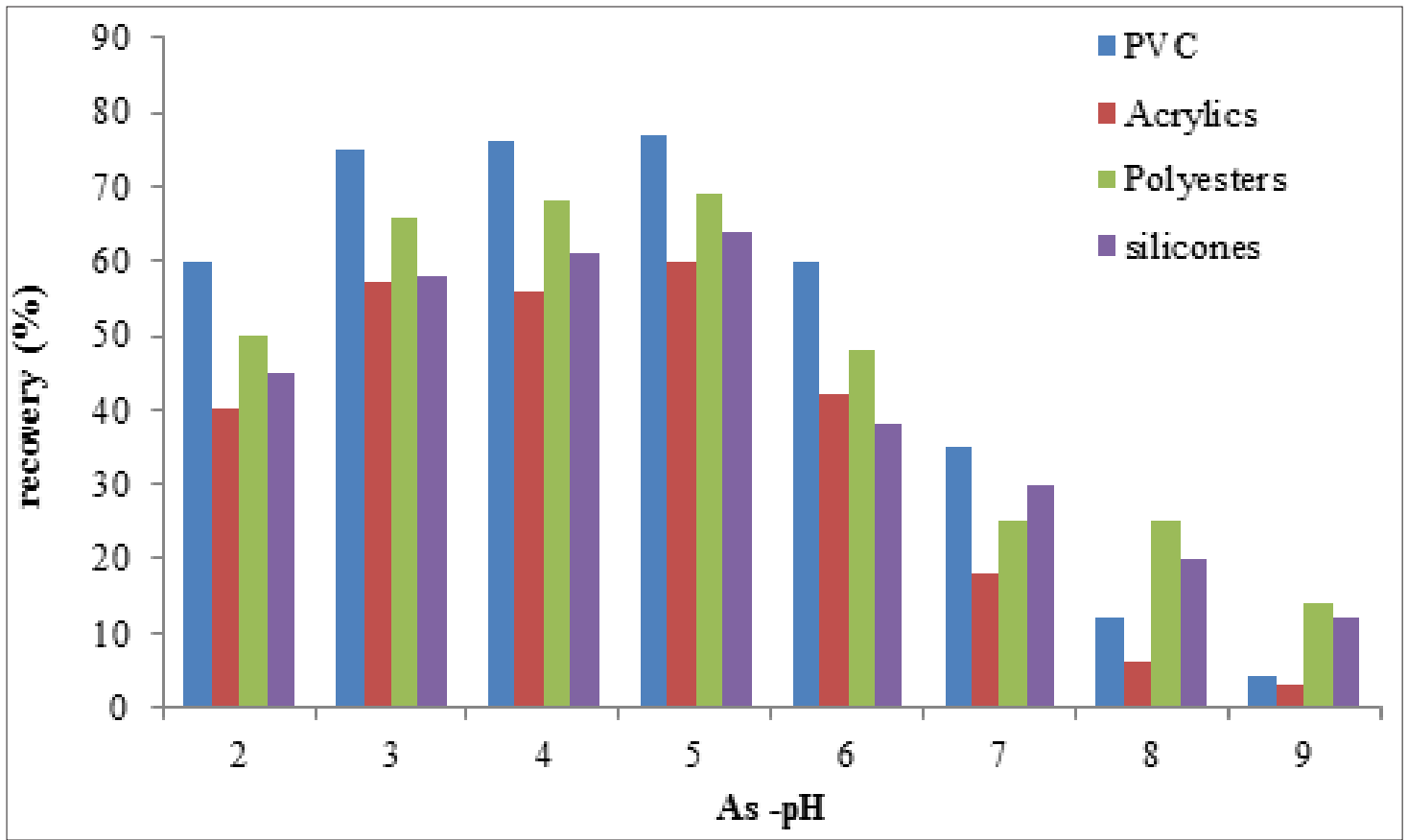

Fig. 6. The effect of $\mathrm{pH}$ on arsenic extraction by microplastics 
talk of awareness. Despite the potential toxicity, there is research currently focusing on method of quantification and identification of microplastics in Nigeria as well as its removal in freshwater system. Also, determination heavy metals in water and microplastics are very important. As a matter of fact, when fully understood and the adverse effects of microplastics on man, his plants and animals are supported with data, the Nigerian government and policy makers with call for a ban of plastics as is currently done in developed countries. Therefore, a call is made here for more studies and awareness of this pollutant because a stich in time serves nine.

\section{Conflict of interest}

The authors declares no conflicts of interest

\section{Acknowledgement}

This work is funded by members of Group Research in Analytical Chemistry, Environment and Climate Change (GRACE\&CC) with funding number GRACE\&CC05/19/FUNDS.

\section{References}

[1] Plastics europe, Plastics-the Facts: An analysis of European plastics production, demand and waste data, (2018). http://www.plasticseurope.org

[2] C. E. Enyoh, A. W. Verla, E. N. Verla, Uptake of microplastics by Plant: a Reason to Worry or to be Happy, World Sci. News, 131 (2019) 256-267.

[3] L. Van Cauwenberghe, A. Vanreusel, J. Mees, C.R. Janssen, Microplastic pollution in deep-sea sediments, Environ. Pollut., 182 (2013) 495-499.

[4] L. Van Cauwenberghe, L. Devriese, F. Galgani, J. Robbens, C. R. Janssen, Microplastics in sediments: A review of techniques, occurrence and effects, Marine Environ, Res,, 111 (2015) 5-17.

[5] A. W. Verla, C. E. Enyoh, E. N. Verla Microplastics, an emerging concern: A review of analytical techniques for detecting and quantifying microplatics, Anal. Method. Environ. Chem. J., 2 (2019) 15-32.

[6] A.W. Verla, C.E. Enyoh, E.N. Verla, K.O. Nwarnorh, Microplastic toxic chemical interaction: a review study on quantified levels, mechanism and implications. Appl. Sci. (2019). Accepted manuscript

[7] M.A. Browne, P. Crump, S.J. Niven, E. Teuten, A. Tonkin, T. Galloway, Accumulation of microplastic on shorelines worldwide: Sources and sinks, Environ. Sci. Technol, 45 (2011) 9175-9179.

[8] C.E. Enyoh, A.W. Verla, E.N. Verla, F.C. Ibe, C.E. Amaobi, Airborne microplastics: a review study on method for analysis, occurrence, movement and risks. Environ. Monit. Assess., (2019). Accepted manuscript

[9] M. Masó, J.M. Fortuño, S. de Juan, M. Demestre, Microfouling communities from pelagic and benthic marine matter to microplastic addition in Chinese loess soil, Chemosphere, 185 (2016) 907917.

[10] Y. Zhang, T. Gao, S. Kang, M. Sillanpää, Importance of atmospheric transport for microplastics deposited in remote areas, Environ. Pollut., 254 (2019) PtA.

[11] E. Riskey, Which countries have banned plastic bags, Curr. Event., (2017) Accessed 27/09/2019. https://study.com/blog/which-countries-havebanned-plastic-bags.html

[12] NESREA, National Environmental Standards and Regulations Enforcement Agency; Laws and Regulations. (2009). https://www.nesrea.gov.ng/ publications-downloads/laws-regulations/

[13] C.E. Enyoh, A.W. Verla, E.N. Verla, S.C. Ihenetu $\mathrm{SC}$, Macrodebris and microplastics pollution in Nigeria: first report on abundance, distribution and composition, Inter. J. Environ. (preprint 2019). https://10.20944/preprints201908.0255.v1 )

[14] J. Reisser, B. Slat, K. Noble, K. du Plessis, M. Epp, M. Proietti, J. de Sonneville, T. Becker, C. Pattiaratchi, The vertical distribution of buoyant plastics at sea: An observational study in the north Atlantic Gyre." Biogeosci., $\left.1 r_{(}\left(r_{+} 0\right) 0 r_{-}\right) r_{9}$.

[15] UNEP, Marine Litter: A Global Challenge, Nairobi, (2009) 232.

[16] J.R. Jambeck, R. Geyer, C. Wilcox, T.R. Siegler, M. Perryman, A. Andrady, R. Narayan, K.L. Law, Plastic waste inputs from land into the ocean, Sci., 347 (2015) 768-771.

[17] C. Schmidt, K. Tobias, W. Stephan, Export of plastic debris by rivers into the sea, Environ. Sci. Technol., 51 (2017) 12246-12253.

[18] P. Jan, A. J. Löhr, F. G. A. J. Van Belleghem, A. M. J. Ragas, Wear and tear of tyres: A stealthy source of microplastics in the environment, Int. J. 
Environ. Res. Pub. Health I $\{$ (2017) 1265. https:// doi.org/10.3390/ijerph14101265.

[19] B.B. Babatunde, O.U. Arinze, Suspended marine litter in Akwa Ibom state, Nigeria: A case study of cross river, QUA Iboe river and Jaja Creek, J. Geography Environ. Earth Sci. Inter., 18 (2018) $1-13$.

[20] J. Lee, S. Hong, Y.K. Song, S.H. Hong, Y. C. Jang, Y.C., M. Jang, W.J. Shim, Relationships among the abundances of plastic debris in different size classes on beaches in South Korea. Marine Pollut. Bull., 77 (2013) 349-354.

[21] H. Liu, X. Yang, G. Liu, C. Liang, S. Xue, H. Chen, C.J. Ritsema, V. Geissen, Response of soil dissolved organic matter to microplastic addition in Chinese loess soil, Chemosphere, 185 (2017) 907917.

[22] A. Lusher, P. Hollman, J. Mendoza-Hill, Microplastics in fisheries and aquaculture: status of knowledge on their occurrence and implications for aquatic organisms and food safety, FAO Fish. Aquacult. Tech. Paper, 615 (2017).

[23] A.I. Catarino, M. Valeria, G.S. William, C.T. Richard, B.H. Theodore, low levels of microplastics (MP) in wild mussels indicate that MP ingestion by humans is minimal compared to exposure via household fibres fallout during a meal, Environ. Pollut., 237 (2018) 675-684.

[24] C.E. Enyoh, Microplastic pollution in Nigeria: A call for concern. 26Th meeting of the Imo State chapter of the chemical society of Nigeria (CSN) held at Imo State University, Nigeria, (2019) 1-15.

[25] E.O. Akindele, M.E. Sonja, H.E.K Jochen, First empirical study of freshwater microplastics in West Africa using gastropods from Nigeria as bioindicators, Limnologica J., 78 (2019) 125708.

[26] E. Briggs, E.A.B. de Moura, H.A. Furusaw, M.E.B. Cotrim, E.E. Oguzie, A.B. Lugao, Microplastics: A Novel method for surface water sampling and sample extraction in elechi Creek, rivers state, Nigeria, characterization of minerals, metals and materials, the minerals, metals and materials society, (2019) 269-281.

[27] C.E. Enyoh, A.W. Verla, We are breathing Plastic; Don't Just Look down, Look up, Presented at the 3rd IMSU World Environment Day International Conference (2019).

[28] A.W. Verla, E.N. Verla, M.A. Chigbo, C.L. Kelechi,
O.S. Ngozi, C.E. Enyoh, Biomonitoring of heavy metals in blood and urine of African children from Owerri Metropolis, Eastern Nigeria. J. Chem. Health Risks, 9 (2019) 11-26.

[29] D. Brennecke, B. Duarte, F. Paiva, I. Caçador, J. Clode, (2016) Microplastics as vector for heavy metal contamination from the marine environment, Estuar. Coast. Shelf Sci., 178 (2016)189-195.

[30] F. Fu, Q. Wang, (2011) Removal of heavy metal ions from wastewaters: A review, J. Environ. Manage., 92 (2011) 407-418.

[31] L. A. Holmes, A. Turner, R. C. Thompson, Adsorption of trace metals to plastic resin pellets in the marine environment, Environ. Pollut., 160 (2012) 42-48.

[32] J. Wang, J. Peng, Z. Tan, Y. Gao, Z. Zhan, Q. Chen, L. Cai, 2017): Microplastics in the surface sediments from the Beijiang River littoral zone: Composition, abundance, surface textures and interaction with heavy metals, Chemosphere 171(2017) 248-258 